\title{
Carryover effects of varying hay concentration on the transition to silage-based feeding of weaned dairy calves
}

\author{
Z.A. Qamar ${ }^{1}$, M.A. Rashid ${ }^{1 \#}$, T.N. Pasha ${ }^{1}$, M.I. Malik ${ }^{1}$ A. Saleem ${ }^{1}$, M. Raza ${ }^{2}$, H.U. Rehman ${ }^{2}$ \& \\ M.S. Yousaf ${ }^{2}$ \\ ${ }^{1}$ Department of Animal Nutrition, University of Veterinary and Animal Sciences, Lahore-54000, Pakistan \\ ${ }^{2}$ Department of Physiology, University of Veterinary and Animal Sciences, Lahore-54000, Pakistan
}

(Received 6 January 2019; Accepted 24 July 2019; First published online 1 January 2020)

\author{
Copyright resides with the authors in terms of the Creative Commons Attribution 4.0 South African Licence. \\ See: http://creativecommons.org/licenses/by/4.0/za \\ Condition of use: The user may copy, distribute, transmit and adapt the work, but must recognise the authors and the South African \\ Journal of Animal Science.
}

\begin{abstract}
Objectives of the experiment were to determine effects of dietary hay concentration in a dry total mixed ration and its carryover effects on intake, growth performance, faecal score, and feed efficiency of weaned dairy calves. Eighteen Friesian $\times$ Jersey weaned calves $(n=6$ calves/treatment) were randomly assigned to three rhodes grass hay treatments (RG13, RG26, and RG39). The experimental diets were rhodes grass hay-based total mixed rations containing 13\%, 26\%, and 39\% chopped hay on a DM basis. The experiment had two phases of four weeks each. In phase 1 (weeks 1-4), weaned calves were fed RG13, RG26, or RG39. Then, in phase 2 (weeks 5-8), all calves were shifted to a maize silage-based diet. All the diets were iso-nitrogenous and were fed ad libitum. Calves were housed in individual pens and had free access to water and feed. Average daily gain and daily dry matter intake were analysed as repeated measures, whereas bodyweight and feed efficiency were analysed using one-way ANOVA. In phases 1 and 2 dry matter intakes were similar. Growth rate decreased linearly with increasing concentration of hay in phase 1 . Overall, daily dry matter intake, average daily gain, change in body condition score and structural measurements were not affected by dietary treatments. However, overall feed efficiency was improved for calves fed RG26 compared with RG13 and RG39. Thus, feeding a moderate level of hay had positive impacts on the transition to a silage-based TMR.
\end{abstract}

Keywords: dietary transition, total mixed ration, intake, growth, feed efficiency, body condition score, faecal score

\#Corresponding author: drafzal@uvas.edu.pk

\section{Introduction}

Growing calves experience a dietary transition from milk and starter to a forage-based diet. The transition period can be stressful if not managed properly, resulting in high morbidity and mortality, and poor growth rates in dairy calves (Drackley, 2008),); whereas a smooth weaning transition increases ADG and reduces the incidence of morbidity in weaned calves. Hay is an important component of a calf ration that is conventionally fed after weaning, in which concentrate and long hay are offered separately to calves. Feeding a TMR has benefits over conventional feeding in terms of weight gain (Nissanka et al., 2010).

Rumen musculature development and capacity are influenced by the physical stimuli provided by the bulk of the ingested material (Beharka et al., 1998). In growing calves, forage provides bulk in the rumen and thus promotes rumen musculature and helps to maintain the integrity of the rumen epithelium (Beharka et al., 1998; Beiranvand et al., 2014). The inclusion of hay in diets of young calves increased intake and improved feed efficiency (FE) by altering the rumen environment (Coverdale et al., 2004). However, a higher inclusion level of forage in a total mixed ration (TMR) decreased average daily gain (ADG) in calves (Hill et al., 2008). Similarly, Hill et al. (2009) showed that ADG and dry matter intake (DMI) declined as roughage increased in the ration of young calves.

Limited information is available on the performance of weaned dairy calves that are shifted from a dry hay-based TMR to a silage-based TMR. Therefore, the objective was to determine the effects of dietary transition on post-weaning intake, growth performance, structural development, faecal consistency and FE in weaned dairy calves. 


\section{Materials and Methods}

The experimental procedures were approved by the Animal Care and Use Committee of UVAS (protocol no. 1246/ 21-11-2017). Eighteen crossbred Friesian $\times$ Jersey male calves that had been weaned at $60 \pm 2.0$ days old, weighing $71.6 \pm 8.6 \mathrm{~kg}$, were randomly assigned to three dietary treatments $(\mathrm{n}=6$ calves/treatment). Treatments consisted of i) RG13, which contained 13\% Rhodes grass (RG) hay in TMR on DM basis); ii) RG26 (26\% RG hay), and iii) RG39 (39\% RG hay). All diets were iso-nitrogenous and fed once daily at 08:00. The total duration of the experiment was eight weeks, including two phases of four weeks each. During phase1 (1-4 week), calves were offered RG13, RG26, and RG39 diets according to their treatments. In phase 2 (5-8 week) all calves were shifted to a maize silage-based TMR. Calves were housed in individual pens of $1.5 \mathrm{~m}^{2}$ and bedded with sand.

During phase 1 fresh TMR was mixed manually and fed ad libitum individually once a day at 08:00. The orts were collected daily before feeding, and feed was adjusted to ensure $10 \%$ of refusal (Table 1). In phase 2, maize silage and hay-based TMR was formulated, and a similar feeding routine was followed from week 5 to 8 (Table 2). Water was available ad libitum throughout the experiment.

Table 1 Ingredient and nutrient composition of hay-based total mixed rations (dry matter basis) fed to crossbred calves from week 1 through week 4 post-weaning

\begin{tabular}{|c|c|c|c|c|}
\hline \multirow{2}{*}{ Ingredients (g/kg of DM) } & \multicolumn{3}{|c|}{ Treatments $^{1}$} & \multirow{2}{*}{$\begin{array}{c}\text { Rhodes grass } \\
\text { hay }\end{array}$} \\
\hline & RG13 & RG26 & RG39 & \\
\hline Rhodes grass hay & 130 & 260 & 390 & \\
\hline Soy hulls & 225 & 170 & 120 & \\
\hline Ground maize & 380 & 300 & 210 & \\
\hline Molasses & 60 & 60 & 60 & \\
\hline Soybean meal & 180 & 185 & 195 & \\
\hline Mineral mixture ${ }^{2}$ & 10 & 10 & 10 & \\
\hline Salt & 5 & 5 & 5 & \\
\hline Lime & 10 & 10 & 10 & \\
\hline \multicolumn{5}{|l|}{ Nutrient composition } \\
\hline Dry matter $\mathrm{g} / \mathrm{kg}$ & 877 & 874 & 871 & 864 \\
\hline Crude protein $\mathrm{g} / \mathrm{kg}$ & 162 & 161 & 162 & 93 \\
\hline Metabolizable energy, MJ/kg & 10.87 & 10.46 & 10.04 & 7.9 \\
\hline Neutral detergent fibre g.kg & 280 & 331 & 383 & 697 \\
\hline Acid detergent fibre $\mathrm{g} / \mathrm{kg}$ & 178 & 204 & 232 & 408 \\
\hline Ash $\mathrm{g} / \mathrm{kg}$ & 74 & 83 & 92 & 97 \\
\hline
\end{tabular}

\footnotetext{
${ }^{1}$ RG13: Total mixed ration (TMR) containing 13\% RG hay on DM basis, RG2: TMR containing 26\% RG hay on DM basis, and RG39: TMR containing 39\% RG hay on DM basis

2 di-calcium phosphate: $70.81 \%$, salt: $18.91 \%$, magnesium sulphate: $8.64 \%$, ferrous sulphate: $8.64 \%$, manganese sulphate $0.49 \%$, zinc sulphate $0.22 \%$, copper sulphate $0.03 \%$, potassium iodide $0.009 \%$, cobalt chloride $0.009 \%$ and sodium selenite: $0.0015 \%$
} 
Table 2 Composition of silage-based total mixed ration (dry matter basis) fed to crossbred calves from week 5 through week 8 post-weaning

\begin{tabular}{|c|c|c|}
\hline Ingredients (g/kg of dry matter) & Silage-based total mixed ration & Maize silage \\
\hline Maize silage & 400 & \\
\hline Rhodes grass hay & 200 & \\
\hline Ground maize & 110 & \\
\hline Soy hulls & 65 & \\
\hline Molasses & 50 & \\
\hline Soybean meal & 140 & \\
\hline Urea & 10 & \\
\hline Mineral mixture ${ }^{1}$ & 10 & \\
\hline Salt & 5 & \\
\hline Lime & 10 & \\
\hline \multicolumn{3}{|l|}{ Nutrient composition } \\
\hline Dry matter g/kg & 500 & 305 \\
\hline Crude protein $\mathrm{g} / \mathrm{kg}$ & 161 & 75 \\
\hline Metabolizable energy, MJ/kg & 9.6 & 9.6 \\
\hline Neutral detergent fibre $\mathrm{g} / \mathrm{kg}$ & 434 & 578 \\
\hline Acid detergent fibre $\mathrm{g} / \mathrm{kg}$ & 311 & 469 \\
\hline Ash $\mathrm{g} / \mathrm{kg}$ & 86 & 53 \\
\hline Calcium g/kg & 9 & 3 \\
\hline Phosphorus g/kg & 5 & 3 \\
\hline
\end{tabular}

Calves were weighed at the start of the trial and then on a weekly basis. Faecal scoring was performed daily using a 1-4 point system in which score 1 was loose and 4 was hard faeces (Ireland-Perry et al., 1993). Body condition scoring was performed at the start of the experiment, then weekly, using a 1-5 scale scoring system with 0.25 increments in measurement (Wildman et al., 1982). Withers height (WH), hip height $(\mathrm{HH})$, heart girth $(\mathrm{HG})$, and body length $(\mathrm{BL})$ were measured at the start and after that weekly (Nemati et al., 2015).

Feed samples were dried at $105{ }^{\circ} \mathrm{C}$ for four hours in a forced draft oven (Memmert UF450TS, Germany) to determine DM. Dried samples were ground to pass through a 1-mm screen using a Wiley mill (model no. 2, Arthur $\mathrm{H}$. Thomas Company, Philadelphia, USA). The CP content $(\mathrm{N} \times 6.25)$ was determined with Kjeldahl apparatus (Gerhardt Kjeldatherm, Germany), and ash contents by combustion at $550{ }^{\circ} \mathrm{C}$ for 5 hours (AOAC, 1991). The concentration of NDF and ADF (Van Soest et al., 1991) were determined sequentially using an Ankom fibre analyser (Ankom2000, Ankom Technologies, USA). Sodium sulphite and heat-stable alpha-amylase (Ankom, Ankom Technologies, USA) were added during the NDF extraction process (Van Soest et al., 1991).

Data were analysed using the PROC MIXED model function of SAS 9.3 (SAS Institute Inc., Cary NC). Weekly measures, including ADG, daily DMI, and faecal score, were analysed using repeated-measures ANOVA. The model included treatment, week, treatment $\times$ week and calf as a random factor. Data for structural measurement, BCS, gain and FE were analysed using one-way ANOVA. To determine the effect of the increasing hay level in the TMR, diet orthogonal polynomial contrasts were used. Initial bodyweights and structural measurements were taken as covariates for the parameters. The results were declared significant at $P<0.05$, and probability values between 0.05 and $\leq 0.10$ were regarded as a trend towards significance. 


\section{Results}

The results of DMI, ADG, FE, and BCS are presented in Table 3. Overall, from week 1 through week 8, DMI was similar between treatments $(P>0.05)$. In phase 1 , DMI tended to decrease linearly $(P=0.07)$ with increasing hay concentration in the dry TMR, RG13 calves consumed 13\% and $16 \%$ more DM than RG26 and RG39, respectively, whereas DMI was not different between treatments in phase 2 .

Table 3 Effect of varying levels of Rhodes grass hay on the transition from a hay-based total mixed ration to a silage-based diet on intake, growth performance, feed efficiency and body condition score of crossbred calves

\begin{tabular}{|c|c|c|c|c|c|c|}
\hline \multirow{2}{*}{ Traits $^{2}$} & \multicolumn{3}{|c|}{ Treatments $^{1}$} & \multirow[b]{2}{*}{ SE } & \multicolumn{2}{|c|}{$P$-value } \\
\hline & RG13 & RG26 & RG39 & & Linear & Trt $\times w k$ \\
\hline \multicolumn{7}{|l|}{ Phase 1} \\
\hline DMI, kg & 2.88 & 2.50 & 2.42 & 0.155 & 0.070 & 0.293 \\
\hline ADG, $\mathrm{kg}$ & 1.12 & 1.00 & 0.75 & 0.066 & 0.002 & 0.363 \\
\hline $\mathrm{FE}^{2}$ & 0.38 & 0.40 & 0.30 & 0.027 & 0.034 & - \\
\hline \multicolumn{7}{|l|}{ Phase-2 } \\
\hline DMI, kg & 3.34 & 3.32 & 3.31 & 0.178 & 0.905 & 0.880 \\
\hline ADG, $\mathrm{kg}$ & 0.84 & 1.08 & 1.05 & 0.035 & 0.001 & 0.004 \\
\hline FE & 0.25 & 0.32 & 0.31 & 0.013 & 0.004 & - \\
\hline \multicolumn{7}{|l|}{ Overall } \\
\hline DMI, kg & 3.11 & 2.90 & 2.87 & 0.153 & 0.322 & 0.631 \\
\hline ADG, $\mathrm{kg}$ & 0.98 & 1.03 & 0.90 & 0.041 & 0.247 & 0.020 \\
\hline FE & 0.31 & 0.35 & 0.31 & 0.012 & 0.852 & - \\
\hline Initial BCS & 2.87 & 2.58 & 2.70 & 0.108 & 0.208 & - \\
\hline Final BCS & 3.25 & 3.12 & 3.17 & 0.100 & 0.760 & - \\
\hline BCS change & 0.38 & 0.54 & 0.46 & 0.058 & 0.179 & - \\
\hline
\end{tabular}

${ }^{1}$ RG13, RG26 and RG39; Total mixed rations containing $13 \%, 26 \%$, and $39 \%$ of Rhodes grass hay (DM basis) that were fed during weeks1 through 4 post-weaning (Phase 1). During weeks 5 through 8 (Phase 2) all calves were fed a total mixed ration that contained $40 \%$ silage and $20 \%$ Rhodes grass hay (DM basis)

${ }^{2}$ ADG: average daily gain (kg/day), BCS: body condition score, DMl: dry matter intake (kg/day), FE: ADG/DMI

A treatment $\times$ week interaction for ADG was observed at weeks 1, 2, 3, 5, and 6 (Figure 1). Overall, a trend $(P=0.089)$ was observed in ADG, with the RG26 group gaining $5 \%$ and $13 \%$ more weight than RG13 and RG39, respectively. In phase 1 , ADG decreased linearly $(P=0.001)$ with increasing concentrations of hay in the TMR with ADG being greatest for RG13 and least for RG39. In phase 2, ADG was greater for RG26 and the RG39, whereas it was lower for RG13 $(P=0.001)$. A treatment $\times$ week interaction $(P<0.05)$ was also observed at weeks 5 and 6 of phase 2 .

During phase 1 and phase 2, FE was highest in RG26 ( $P<0.05)$. In phase 1, FE of RG39 was 23\% and $18 \%$ lower than RG26 and RG13, respectively. Initial and final BCS and changes in them were not affected $(P>0.05)$ by the diet that was consumed in phase 1.

Similarly, initial, final and changes in structural measurements including $\mathrm{WH}, \mathrm{HH}, \mathrm{HG}$, and $\mathrm{BL}$, were similar $(P>0.05)$ among treatments (Table 4). The results of faecal score are presented in Table 5. During phases 1 and 2, RG13 calves exhibited loose faeces compared with RG26 and RG39. A treatment $\times$ week interaction was also observed in weeks 5 and 6. 


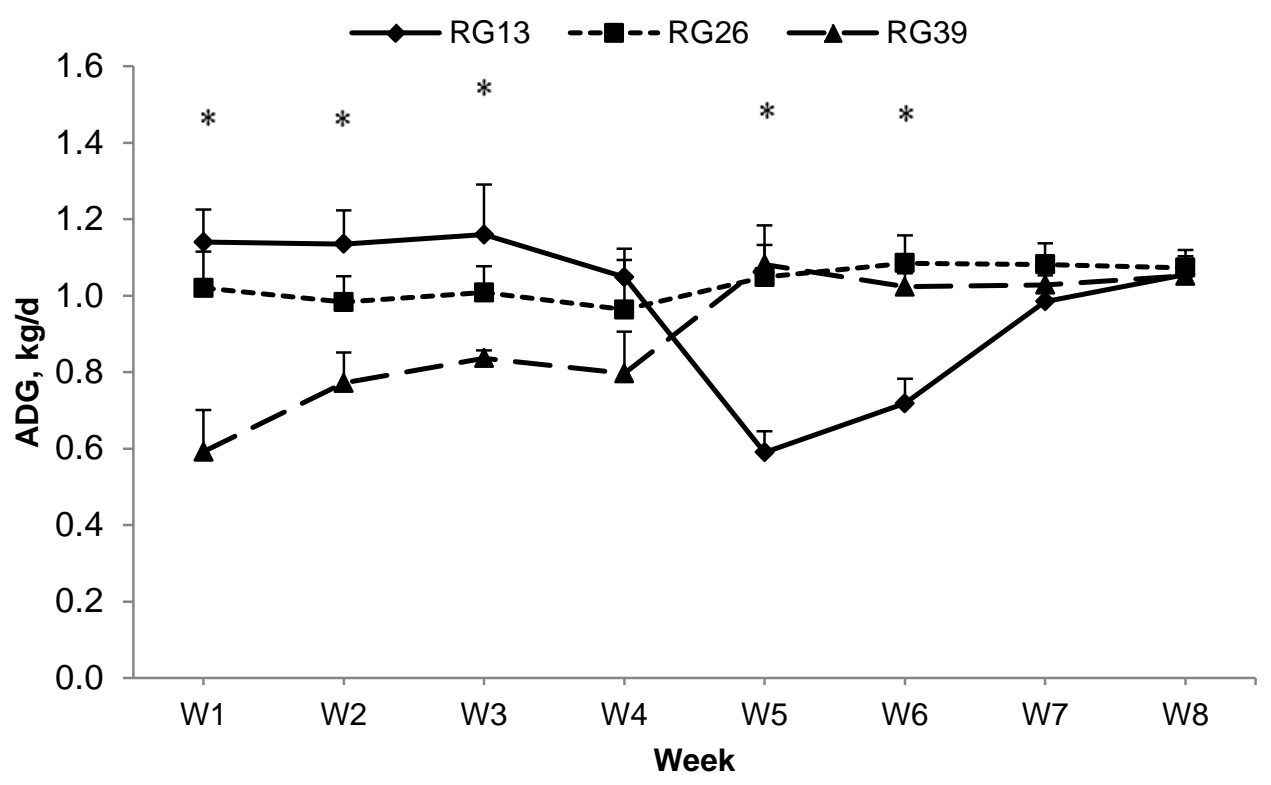

Figure 1 Weekly weight gain of crossbred calves fed Rhodes grass hay-based total mixed rations

RG13: Total mixed ration (TMR) containing 13\% Rhodes grass (RG) hay (DM basis), RG26: TMR containing 26\% RG hay (DM basis), RG39: TMR containing 39\% RG hay (DM basis) RG that were fed in week 1 through week 4 . A TMR that contained $40 \%$ silage and $20 \%$ RG hay (DM basis) was fed in week 5 through week 8 . For each point, * shows significant difference at $P<0.05$

Table 4 Effect of varying hay levels in post-weaning total mixed rations on body measurements of crossbred calves

\begin{tabular}{|c|c|c|c|c|c|c|}
\hline \multirow{2}{*}{ Variables } & \multicolumn{3}{|c|}{ Treatments $^{1}$} & \multirow[b]{2}{*}{ SE } & \multicolumn{2}{|c|}{$P$-value } \\
\hline & RG13 & RG26 & RG39 & & Linear & Quadratic \\
\hline \multicolumn{7}{|c|}{ Withers height, $\mathrm{cm}$} \\
\hline Initial & 86.7 & 88.1 & 89.0 & 0.92 & 0.286 & 0.163 \\
\hline Final & 97.0 & 99.1 & 99.1 & 1.05 & 0.399 & 0.914 \\
\hline Gain & 10.1 & 10.3 & 11.0 & 0.98 & 0.398 & 0.910 \\
\hline \multicolumn{7}{|c|}{ Hip height, cm } \\
\hline Initial & 90.2 & 92.2 & 93.2 & 1.10 & 0.22 & 0.156 \\
\hline Final & 98.9 & 101.9 & 102.4 & 1.31 & 0.375 & 0.995 \\
\hline Gain & 8.8 & 9.2 & 9.8 & 0.72 & 0.372 & 0.996 \\
\hline \multicolumn{7}{|c|}{ Heart girth, $\mathrm{cm}$} \\
\hline Initial & 93.3 & 94.1 & 96.5 & 1.17 & 0.68 & 0.077 \\
\hline Final & 108.2 & 111.1 & 111.3 & 1.44 & 0.145 & 0.216 \\
\hline Gain & 16.5 & 14.8 & 14.8 & 1.55 & 0.144 & 0.215 \\
\hline \multicolumn{7}{|c|}{ Body length, cm } \\
\hline Initial & 91.8 & 91.9 & 92.0 & 1.40 & 0.918 & 0.989 \\
\hline Final & 107.1 & 108.3 & 109.9 & 1.74 & 0.056 & 0.885 \\
\hline Gain & 17.9 & 16.4 & 15.3 & 0.84 & 0.057 & 0.886 \\
\hline
\end{tabular}

\footnotetext{
${ }^{1}$ RG13, RG26 and RG39; Total mixed rations containing 13\%, 26\%, and 39\% of Rhodes grass hay (DM basis) that were fed during weeks1 through 4 post-weaning (Phase 1). During weeks 5 through 8 (Phase 2) all calves were fed a total mixed ration that contained $40 \%$ silage and $20 \%$ Rhodes grass hay (DM basis)
} 
Table 5 Effect of feeding varying hay levels in post-weaning total mixed rations on faecal score of crossbred calves

\begin{tabular}{|c|c|c|c|c|c|c|c|}
\hline \multirow{2}{*}{ Items } & \multicolumn{3}{|c|}{ Treatments $^{1}$} & \multirow{2}{*}{ SEM } & \multicolumn{3}{|c|}{$P$-value } \\
\hline & RG13 & RG26 & RG39 & & Linear & Week & Trt $\times w k$ \\
\hline \multicolumn{8}{|c|}{ Faecal score } \\
\hline Phase 1 & 3.21 & 3.37 & 3.39 & 0.05 & 0.03 & $<0.001$ & 0.198 \\
\hline Phase 2 & 3.80 & 3.82 & 3.87 & 0.03 & 0.16 & 0.285 & 0.004 \\
\hline Overall & 3.50 & 3.59 & 3.63 & 0.04 & 0.04 & - & - \\
\hline
\end{tabular}

\footnotetext{
${ }^{1}$ RG13, RG26 and RG39; Total mixed rations containing 13\%, 26\%, and 39\% of Rhodes grass hay (DM basis) that were fed during weeks1 through 4 post-weaning (Phase 1). During weeks 5 through 8 (Phase 2) all calves were fed a total mixed ration that contained $40 \%$ silage and $20 \%$ Rhodes grass hay (DM basis)
}

\section{Discussion}

During phase 1, DMI decreased with increasing concentration of RG hay. Higher dry roughage levels increased the long particle distribution in the diets, thus reducing DMI (Greter et al., 2008; Groen et al., 2015). Decreased DMI can be associated with the higher NDF contents of the RG26 and RG39 compared with the RG13 diet (Hill et al., 2010). The results for similar DMI in phase 2 are in line with those reported by Groen et al. (2015), which suggests that increasing the RG hay concentration had no carryover effect on DMI when calves transitioned to a silage-based TMR.

In weeks 1 through 4, ADG was lowest for RG39. Lower ADG in the RG39 calves may be associated with lower DMI during phase 1. Other possible explanations might be decreased DM digestibility (Hill et al., 2010; Groen et al., 2015) because of the higher concentration of dry roughage in the diet (Yang et al., 2001) or the decrease in energy contents of the diet $(11.00,10.54$, and $10.04 \mathrm{MJ} / \mathrm{kg}$ of ration) with increasing amounts of hay in TMR (Van Ackeren et al., 2009 ). A treatment and week interaction was observed for higher ADG during weeks 5 and 6 of the experiment in RG26 and RG39. This may be related to better adaptability of rumen microbiota of the RG23 and RG26 treatment calves, which had previously been exposed to high forage diets in phase 1. Decreased weight gain in RG13 at weeks 5 and 6 following the dietary transition to a high-fibre diet could be related to the higher level of concentrate in the diet in phase 1 , as high concentrate diets are known to decrease ruminal $\mathrm{pH}$ and reduce the population of rumen cellulolytic bacteria (Russell \& Wilson, 1996). Another possible mechanism for the higher growth in RG 26 and RG 39 in phase 2 may be associated with well-established cellulolytic microbiota in RG26 and RG39, because previous exposure to high fibre, and consequently better fibre utilization, improved weight gain.

Animals reared on a high-fibre diet exhibit lower FE, which might be associated with poor digestibility of fibre (Hill et al., 2010; Groen et al., 2015). Improvements in FE occurred when high forage diets were replaced with high concentrate diets (Zanton \& Heinrichs, 2007). Contrary to the current results, Hill et al. (2010) reported no difference in feed to gain ratio when varying levels of chopped grass hay were included in a weaned calf diet. A similar FE that was reported in a study by Hill et al. (2010) might be associated with lower inclusion $(0 \%, 3 \%, 6 \%$, and $9 \%$ ) levels of hay. However, in the current experiment, the inclusion of RG was $13 \%, 26 \%$, and $39 \%$, which is much higher than those reported by Hill et al. (2010). In phase 2, RG26 and RG39 showed 15\% and 14\% higher FE than RG13. Poor performance in RG13 might be associated with higher intake of concentrate, consequently higher short-chain fatty acid production, lower ruminal $\mathrm{pH}$ (Laarman, et al., 2012) and ruminal contraction (Owens et al., 1998). Another possible mechanism is the reduction in absorption of volatile fatty acids (Leonhard-Marek et al., 2007) because of keratinization of rumen papillae (Steele et al., 2011). The better performances of RG26 and RG39 may be associated with better rumen development owing to higher NDF contents in the diet compared with RG13, Similar results were reported by Terré et al. (2013).

In the current experiment, no differences in body dimensions were observed between treatments, despite changes in ADG that can be attributed to the treatments. Likewise, no significant effects on BCS were observed. The current results for structural measurements were similar to previous findings in calves (Enevoldsen et al., 1997; Hill et al., 2010).

The loose faecal consistency that was observed in RG13 in phase 1 was associated with lower effective fibre intake because of less fibre in the diet. Higher grain intake in RG13 calves might have increased the post-ruminal flow of starch contents, leading to abnormal fermentation in the large intestine 
and loose faeces. Kleen et al. (2003) reported increased rumen osmolality, followed by a lower intake of effective fibre and higher starch intake, resulting in diarrhoea from the increased movement of water into the rumen.

\section{Conclusion}

A medium level of hay (26\% RG on DM basis) in the diet is better for a smooth weaning transition and dietary adaptability of Friesian $\times$ Jersey calves from hay to a silage-based TMR during the post-weaning period. Growth performance and FE were improved in calves fed a diet that contained $26 \%$ RG on a DM basis.

\section{Acknowledgements} experiment.

The authors are thankful to the Punjab Agricultural Research Board for providing the feed and animals for this

\section{Authors' Contributions}

ZAQ did data collection and write up, MAR participated in the planning and writing up the experiment, TNP was involved in formatting and revision. MIM carried out the critical revision, AS was in charge of formatting and revision. MR did laboratory analysis. HUR wrote up the document. MSY did critical revisions.

\section{Conflict of Interest Declaration}

The authors declare there is no conflict of interest.

\section{References}

AOAC, 1991. Official methods of analysis. 16th ed. Association of Official Analytical Chemists International, Washington, DC.

Beharka, A., Nagaraja, T., Morrill, J., Kennedy, G. \& Klemm, R., 1998. Effects of form of the diet on anatomical, microbial, and fermentative development of the rumen of neonatal calves. J. Dairy Sci. 81, 1946-1955. DOI: 10.3168/jds.s0022-0302(98)75768-6

Beiranvand, H., Ghorbani, G., Khorvash, M., Nabipour, A., Dehghan-Banadaky, M., Homayouni, A. \& Kargar, S., 2014. Interactions of alfalfa hay and sodium propionate on dairy calf performance and rumen development. J. Dairy Sci. 97, 2270-2280. DOI: 10.3168/jds.2012-6332

Coverdale, J., Tyler, H., Quigley III, J.D. \& Brumm, J., 2004. Effect of various levels of forage and form of diet on rumen development and growth in calves. J. Dairy Sci. 87, 2554-2562. DOI: 10.3168/jds.s0022-0302(04)73380-9

Drackley, J.K., 2008. Calf nutrition from birth to breeding. Vet. Clin. Food Anim. Pract. 24, 55-86. DOI: 10.1016/j.cvfa.2008.01.001

Enevoldsen, C. \& Kristensen, T., 1997. Estimation of body weight from body size measurements and body condition scores in dairy cows. J. Dairy Sci. 80, 1988-1995. DOI: 10.3168/jds.s0022-0302(97)76142-3

Greter, A., DeVries, T. \& Von Keyserlingk, M., 2008. Nutrient intake and feeding behavior of growing dairy heifers: Effects of dietary dilution. J. Dairy Sci. 91, 2786-2795. DOI: 10.3168/jds.2008-1052

Groen, M., Steele, M. \& DeVries, T., 2015. Effect of straw inclusion rate in a dry total mixed ration on the behavior of weaned dairy calves. J. Dairy Sci. 98, 2693-2700. DOI: 10.3168/jds.2014-8978

Hill, T., Bateman II, H., Aldrich, J. \& Schlotterbeck, R., 2008. Effects of the amount of chopped hay or cottonseed hulls in a textured calf starter on young calf performance. J. Dairy Sci. 91, 2684-2693. doi: 10.3168/jds.2007-0935.

Hill, T., Bateman II, H., Aldrich, J. \& Schlotterbeck, R., 2009. Roughage for diets fed to weaned dairy calves. Prof. Anim. Scient. 25, 283-288. DOI: 10.15232/S1080-7446(15)30719-1

Hill, T., Bateman II, H., Aldrich, J. \& Schlotterbeck, R., 2010. Roughage amount, source, and processing for diets fed to weaned dairy calves. Prof. Anim. Scient. 26, 181-187. DOI: 10.15232/s1080-7446(15)30578-7

Ireland-Perry, R. \& Stallings, C., 1993. Fecal consistency as related to dietary composition in lactating Holstein cows. J. Dairy Sci. 76, 1074-1082. DOI: 10.3168/jds.S0022-0302(93)77436-6

Kleen, J., Hooijer, G., Rehage, J. \& Noordhuizen, J., 2003. Subacute ruminal acidosis (SARA): A review. Transbound. Emerg. Dis. 50, 406-414. DOI: 10.1046/j.1439-0442.2003.00569.x

Laarman, A.H., Sugino, T. \& Oba, M., 2012. Effects of starch content of calf starter on growth and rumen pH in Holstein calves during the weaning transition. J. Dairy Sci. 95, 4478-4487. DOI: 10.3168/jds.2011-4822

Leonhard-Marek, S., Becker, G., Breves, G. \& Schröder, B., 2007. Chloride, gluconate, sulfate, and short-chain fatty acids affect calcium flux rates across the sheep forestomach epithelium. J. Dairy Sci. 90, 1516-26. DOI: 10.3168/jds.s0022-0302(07)71637-5

Nemati, M., Amanlou, H., Khorvash, M., Moshiri, B., Mirzaei, M., Khan, M. \& Ghaffari, M., 2015. Rumen fermentation, blood metabolites, and growth performance of calves during transition from liquid to solid feed: Effects of dietary level and particle size of alfalfa hay. J. Dairy Sci. 98, 7131-7141. DOI: 10.3168/jds.2014-9144

Nissanka, N., Bandara, R. \& Disnaka, K., 2010. A comparative study on feeding of total mixed ration vs conventional feeding on weight gain in weaned Friesian heifers under tropical environment. J. Agric. Sci. 5, 42-51.

Owens, FN., 1988. Ruminal fermentation. In: D.C, Church (ed.), The ruminant animal. Digestive physiology and nutrition. Prentice Hall, Englewood Cliffs, NJ, USA, p. 145.

Russell, J.B. \& Wilson, D.B., 1996. Why are cellulolytic bacteria unable to digest at low pH. J. Dairy Sci. 79, 1503-1509. DOI: 10.3168/jds.s0022-0302(96)76510-4 
SAS, 2012. Version 9.3. SAS Institute Inc., Cary, NC., USA.

Steele, M.A., Croom, J., Kahler, M., AlZahal, O., Hook, S.E., Plaizier, K. \& McBride, B.W., 2011. Bovine rumen epithelium undergoes rapid structural adaptations during grain-induced subacute ruminal acidosis. Am. J. Physiol. Regul. Integr. Comp. Physiol. 300, 1515-1523. DOI: 10.1152/ajpregu.00120.2010

Terré, M., Pedrals, E., Dalmau, A., \& Bach, A., 2013. What do preweaned and weaned calves need in the diet: A high fiber content or a forage source. J. Dairy Sci. 96(8), 5217-5225. DOI: 10.3168/jds.2012-6304

Van Ackeren, C., Steingaß, H., Hartung, K., Funk, R. \& Drochner, W., 2009. Effect of roughage level in a total mixed ration on feed intake, ruminal fermentation patterns and chewing activity of early-weaned calves with ad libitum access to grass hay. Anim. Feed Sci. Technol. 153, 48-59. DOI: 10.1016/j.anifeedsci.2009.05.009

Van Soest, P.J., Robertson, J.B. \& Lewis, B., 1991. Symposium: Carbohydrate methodology, metabolism, and nutritional implications in dairy cattle. J. Dairy Sci. 74, 3583-3597.

Wildman, E., Jones, G., Wagner, P., Boman, R., Troutt, H. \& Lesch, T., 1982. A dairy cow body condition scoring system and its relationship to selected production characteristics. J. Dairy Sci. 65, 495-501. DOI: 10.3168/jds.S00220302(82)82223-6

Yang, W.Z., Beauchemin, K.A. \& Rode, L.M., 2001. Effects of grain processing, forage to concentrate ratio, and forage particle size on rumen $\mathrm{pH}$ and digestion by dairy cows. J. Dairy Sci. 84(10), 2203-2216. DOI: 10.3168/jds.s00220302(01)74667-x

Zanton, G. \& Heinrichs, A., 2007. The effects of controlled feeding of a high-forage or high-concentrate ration on heifer growth and first-lactation milk production. J. Dairy Sci. 90, 3388-3396. DOI: 10.3168/jds.2007-0041 